\title{
THE PATERNAL POWER IN MOHAMMEDAN LAW.
}

Before the age of Mahomet the tribes inhabiting the Arabian peninsula were each governed by their own peculiar laws, although they had many institutions in common, in part the legacy of ancient Semitic civilization, in part the result of the similarity of social and economic conditions. Dr. Robertson Smith has discovered among them institutions resembling the Hindu nivoga, and the sahodha and kanina sonships of India.'

The Mohammedan resembles the Hindu and the Hebrew laws. in being intimately bound up with religion, and in being contained in the inspired writings. The Koran and the sayings of the Prophet as handed down by tradition are the foundation upon which the whole structure of the Mohammedan law has been built, and the Koran, like the Pentateuch, when cited in judicial matters is called by way of distinction al Sharra, or the Law. ${ }^{2}$ As it stands, it is the combination of Arabian customs, of the laws of the Talmud and of the eastern Roman law. ${ }^{3}$

The Mohammedan law is another refutation of the statement often made in an almost axiomatic form, that an inferiority in the position of women is co-existent with an extensive paternal power. With the exception of the right of the father to give his children in marriage, under certain circumstances presently to be considered, the provisions of the Mohammedan law are in accord with modern, Western conceptions of the relations between father and child. It is true that mutilations of the persons of children and the forcing them into prostitution are of frequent occurrence, but these are but instances of the conflict between practice and law from which Western civilization is not entirely free. It is the fault not of the law, but of its administration.

As is the case wherever polygamy exists, the father exercises his atithority over all his children, whether born of a principal wife, of a concubine, or of a slave. The Mohammedan stands almost alone among all the Eastern laws in not giving prominence to the

\footnotetext{
1 "Marriage and Kinship in Early Arabia," pp. 44, 110; Kohler, "Vorislamitisches Recht," p. 243.

2 Tornauw, "Moslemisches Recht," p. I.

3 Kremer, "Culturgeschichte," I, p. 535 and passim.
} 
institution of adoption. There is a kind of adoption, zerilla mawalât, but this gives only mutual rights of inheritance and is terminable at the will of either party. ${ }^{1}$

Among the Arabian tribes the exposition of young children was a common practice, as the many provisions against it in the Koran attest. "Kill not your children," says the Prophet, "for fear of being brought to want, we will provide for them and for you, verily, the killing of them is a great sin." 2 And again, "They are utterly lost who have slain their children foolishly."3

Little mention is made in the Koran of the rights of the father, and the precepts of filial reverence and obedience are entirely general in their character. It should be noted, too, that wherever polygamy exists the relations between each mother and her own children are much more intimate than those of the father with his children.

The Hedáva contains a curious provision forbidding a son to shoot at his father even when the father is serving in the army of the enemy, or to throw a stone at him when he is undergoing the punishment of lapidation for zinna.

The Mohammedan law books contain numerous and often conflicting rules upon the rights of the father in respect to the marriage of his children. The father has the right to give his minor son or daughter in marriage to any person whatsoever, even to a slave, and such act is binding on the child after his majority, as are also any stipulations concerning dowry which the father may have entered into. ${ }^{5}$ And, as a matter of fact, marriages of female children under the age of puberty are frequent. The father possesses the same right over his insane children, of whatever age, and his act can not be rescinded by the child even upon regaining reason. Some authorities ' hold that a father may validly give in marriage a daughter who has attained her majority, without her consent, but the better opinion seems to be against such a right; thus Fatawa Alamgiri" says that "not even a father or the sultan can lawfully 3 Adoption was in use among the Arabs but was abolished by Mahomet.
Smith, p. 44 .

2 Koran, c. XVII., p. 230.

${ }^{8}$ Ibid, c. VI., p. II3. Cf. Ibid, p. II4; c. LXXII., p. $48 \mathrm{r}$; c. XVI., p. 218

4 II., p. 282. This applies to all ancestors.

5 " Hedàya," I., pp. 100-102, II5, II6; Querry, "Droit musulman," Liv. XIX., Tit. I, Sec. I, c. $2, \S \S 66,67$ $\S 73$.

" "Tagore Lectures (I873)," X., ccxxiv; Khalil-Ibn-Ishak, II., p. 327 ; Querry,

7 Khalil-Ibn-Ishak, II., pp. $327,328$.

${ }^{8} \mathrm{I} ., 45$, quoted in "Tagore Lectures 1873),"X., ccxxiv; Querry, \$69. 
contract a woman in marriage who is adult and of sound mind, without her own permission, whether she is a virgin or sayvibah." On the other hand a daughter of marriageable age (majority), whose father maliciously refuses to give her in marriage at all, has a right to appeal to the tribunals. ${ }^{x}$

"In consequence of the fact that the child belongs to the father the law impliedly admits that the property of the child, up to a certain point, belongs to the father. The Prophet has said, 'the child and its property belongs to the father'." 2 The sale by the father of property belonging to a minor child, at a proper price and without fraudulent intent, is valid. ${ }^{3}$ The Hedava gives the father the right to pledge the child's property for his own debt, a right which is, however, not undisputed. But if the pledge is forfeited, the father becomes responsible to the child for its value." The father may also retain such property as security for a debt owing from the infant to him, or to another infant child of his, or to his own slave who is a merchant. The father has the right of pre-emption of his child's property.

A doctrine analogous to the last is enunciated in the following case from the Hedáva which, as containing a curious piece of legal reasoning, is given in full: "If a father enjoys the female slave of his son, and she produce a child and he (the father) claim it, the slave becomes his am acalid and he is answerable to his son for her value; but he is not so for her dowry, because a father being at liberty to possess himself of the property of his son, whenever that may be requisite to his own preservation, it follows that he may possess himself of his son's slave when he requires her for the preservation of his progeny, since he thereby provides for his own continuance, he being virtually continued in his offspring; but the preservation of the progeny being a matter of less immediate importance than that of his life, he must pay a price in exchange for the slave, whereas he may take his son's victuals without paying any price."

1 Khalil-Ibn-Ishak, II., p. 34I. Querry recommends that the father's consent be obtained in the case of the marriage of major children. L. c. § III.

2 Khalil-Ibn-Islak, IV., P' 359.

3 "Tagore Lectures," XVI., D. L. XV.

4 "Hedàya," IV., p. 214 ; "Tagore Lectures (1873)," XVI., DLX, DLXI.

s "Hedàya," IV., p. 214 ; "Tagore Lectures (1873)," XVI., DLVIII, DLIX.

c "Hedàya," I., p. I 70. 
The father can bind his infant son by contract entered into in the child's behalf, and the child does not have the option of annulling it upon attaining majority. ${ }^{2}$ But even a minor child of sound mind who has reached years of discretion, can make a valid testament. ${ }^{2}$

Children of every age are under the ubligation of supporting their indigent parents, a duty based in part on the text, in the Koran, "Thy Lord has commanded that ye show kindness unto your parents, whether the one of them, or both of them attain to old age with thee."

Both sons and daughters are freed from the paternal power upon attaining majority ; and a daughter is emancipated by her marriage. ${ }^{5}$

Bibliography: Hamilton, Charles, The Hedaya or Guide. A Commentary on Mussulman Law, London, I79I ; Kohler, J., Ueber das vorislamitische Recht der Araber. (Zeitschrift fur vergleichende Rechtswissenschaft, Band VIII.); Kremer, Alfred von, Culturgeschichte des Orients unter den Chalifen, Wien, I875; Perron, Precis de jurisprudence musulmane par Khalil-Ibn-Ishak. (Exploration scientifique de l'Algerie,) Paris, I848-1852; Querry, A., Droit musulman. Recueil de lois concernant les musulmans schyites, Paris, 1871; Sale, George, The Koran, Philadelphia, I850; Shama Churun Sircar, The Muhammedan Law, (Tagore Law Lectures, 1873), Calcutta, I873; Smith, W. Robertson, Kinship and Marriage in Early Arabia, Cambridge, I885; Tornauw, Nicholaus von, Das moslemische Recht, Leipzig, 1855 .

UnIVERSity of TeXas. Charles Henry Huberich.

1 " Tagore Lectures (1873)," X., CCXX. Note.

2 Khalil-Ibn-Ishak, IV., p. 64 .

${ }^{3}$ C. XVII., p. 229. Cf. c. VI., p. Ir4; "Hedaya," II., pp. 4Ir, $4^{12}$; KhalilIbn-Ishak, III., pp. 153 , I54.

1 Majority in both sexes is determined by the presence of signs of puberty,or by attaining a certain age (varying from fifteen to eighteen in the authorities.) "Hedaya," III., pp. 482. 483; Khalil-Ibn-Ishak, IV., pp. 60, 6I; "Tagore Lectures (1873)," XVI., DLII. From this time until their twenty-fifth year children are in cura, an institution evidently borrowed from the Roman law.
Kremer, I., p 539.

${ }^{5}$ Khalil-Ibn-Ishak, IV., pp. 64, 65 ; Querry, $\$ 72$. 